\section{0}

If there's any lesson to learn from biomedicine from the past year, it's to expect the unexpected. Who would have thought a year ago that the patents on the breast cancer genes $B R C A 1$ and $B R C A 2$, held by Myriad Genetics, would be overturned by a US federal court? Or that a federal judge would temporarily upend President Barack Obama's executive order allowing funding for research involving human embryonic stem cells?

Likewise, 2010 saw a shake-up for the genetic testing industry after the US Food and Drug Administration (FDA) and Government Accountability Office voiced concerns about the direct-to-consumer spit kits. Meanwhile, some individuals claiming to cure patients with stem cell treatments also drew the ire of regulatory agencies. In August, the FDA tried to crack down on Colorado-based Regenerative Sciences, while in the UK, Robert Trossel lost his doctor's license after treating multiple sclerosis sufferers with stem cell injections.

Susan Reverby, a women's studies professor at Wellesley College in Massachusetts, also discovered evidence of immoral medical practice when she stumbled across documents revealing that the US government had sponsored clinical trials in Guatemala in which people were deliberately exposed to syphilis during the 1940s. Other heartbreaking news came in February when Amy Bishop, a neurobiologist at the University of Alabama in Huntsville allegedly killed three faculty members and injured three others.

But there was hopeful research news, too. China's National Natural Science Foundation made a surprise announcement in January that it had launched a medical branch similar to the US National Institutes of Health. And cancer researchers rejoiced in April when Seattlebased Dendreon received the regulatory go-ahead for the world's first cancer vaccine.

In the following pages of our end-of-year special, we take a tour of the past twelve months and review the breakthroughs and busts of 2010.

\title{
The Yearbook
}

\section{We list key people who made headlines this year, either by standing up for what they saw as right or by stopping what they felt was wrong.}

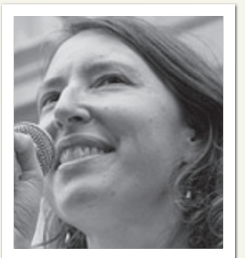

Jenny Rohn Most vital

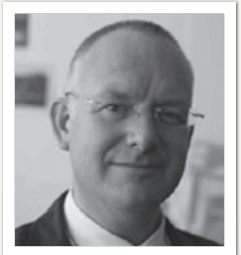

Bruce Charlton Most hypothetical

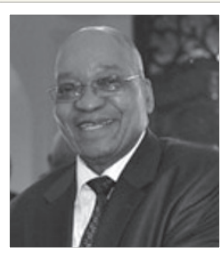

Jacob Zuma Most testy
Threats of budget cuts can leave some researchers paralyzed by stress. But for Rohn, a cell biologist at University College London, proposed cuts to science funding were a call to action. In September, she launched the Science is Vital campaign, which rallied several thousand people for a one-day protest outside the UK Treasury building. When the government later finalized austerity measures, allocations for science were dealt a lighter blow than other sectors.

What would it be like if Bruce Charlton were still editor in chief of the journal Medical Hypotheses? Alas, we won't know the answer to that hypothetical question. Following the publication of a paper questioning the causal link between HIV and AIDS, the journal's publisher Elsevier pushed for Medical Hypotheses to adopt peer review. Charlton stood by his guns that doing so would turn the journal into a "zombie" publication and was ultimately forced out.

Zuma, the president of South Africa, is no stranger to controversy. At a 2006 court case in which he faced accusations of rape, of which he was later acquitted, he said that he took a shower after having had sex to cut his risk of contracting HIV. In a turnaround, Zuma was applauded this year for taking an HIV test in public (he tested negative) and for encouraging others in the country to check their HIV status.

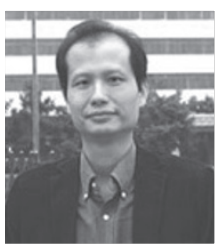

Fang Shimin Least likely to back down

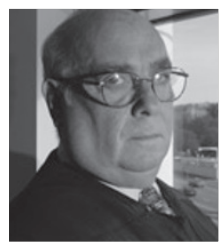

Royce Lamberth Most likely to start a fight

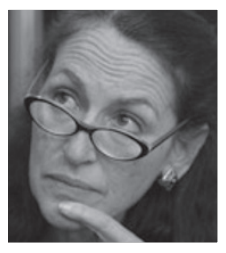

Margaret Hamburg Least likely to have egg on her face
Chinese blogger Shimin has investigated and exposed numerous counts of scientific misconduct. But even writing under a pen name ('Fang Zhouzi') did not protect him from a physical attack, in which he says he was chased down by assailants wielding a hammer. Shimin suffered only minor injuries, but the incident brought attention to the perils faced by journalists reporting on fraud in China.

Lamberth, a US federal district court judge, can start a fight-but it's not the physical kind. In August, Lamberth issued a temporary injunction blocking President Barack Obama's executive order expanding federal funding for research involving embryonic stem cells, a legal action that reignited the debate over the government's support for this controversial field.

A Salmonella outbreak that sickened hundreds and led to the largest egg recall in US history served as a rallying cry for Hamburg, who, as commissioner of the Food and Drug Administration, called on lawmakers to give the agency greater power to issue mandatory recalls of food products. Under her leadership, "the agency has made substantial progress in reducing conflicts of interest among members" of its drug advisory committees, according to the New York Times. 